\title{
Current trends in gastric cancer treatment in Europe
}

\author{
Satoshi Kamiya', Ioannis Rouvelas ${ }^{1,2}$, Mats Lindblad'1,2, Magnus Nilsson ${ }^{1,2}$ \\ 'Department of Surgery, Centre of Digestive Diseases, Karolinska University Hospital, Stockholm SE-14186, Sweden. \\ ${ }^{2}$ Division of Surgery, Department of Clinical Science, Technology and Intervention (CLINTEC), Karolinska Institutet, Stockhom \\ SE-14186, Sweden.
}

Correspondence to: Dr. Magnus Nilsson, Department of Surgery, Centre of Digestive Diseases, Karolinska University Hospital, Stockholm SE-14186, Sweden. E-mail: magnus.nilsson@ki.se

How to cite this article: Kamiya S, Rouvelas I, Lindblad M, Nilsson M. Current trends in gastric cancer treatment in Europe. $J$ Cancer Metastasis Treat 2018;4:35. http://dx.doi.org/10.20517/2394-4722.2017.76

Received: 21 Nov 2017 First Decision: 5 Feb 2018 Revised: 13 Feb 2018 Accepted: 6 Jun 2018 Published: 17 Jul 2018

Science Editors: Lucio Miele Copy Editor: Jun-Yao Li Production Editor: Huan-Liang Wu

\begin{abstract}
Gastric cancer is one of the major causes of cancer-related deaths, despite the gradual decrease of its incidence in the West. Minimally invasive procedures, such as endoscopic resection and laparoscopic gastrectomy, have been successfully introduced in European high-volume centres, in the treatment of early gastric cancer. Regarding advanced, localized gastric cancer a number of prospective trials have been completed in search of better therapeutic options, aiming to optimize the efficacy $v s$. adverse effect ratio. From the results of these prospective randomized trials, the therapeutic strategy has in the last decades shifted emphasis from adjuvant therapy to neoadjuvant or perioperative chemotherapy, in curatively intended treatment. Moreover, recent studies have shown promising results in the use of molecular targeted agents, both in perioperative and palliative settings. The introduction of molecularly targeted therapy will enable a personalized approach based on each patient's and tumor's characteristics, maximizing the benefits from chemotherapy. The present review article focuses on recent therapeutic trends, as well as future perspectives, of surgical and oncological gastric cancer treatment in the Western setting, mainly based on landmark clinical trials.
\end{abstract}

Keywords: Gastric cancer, surgery, neoadjuvant, adjuvant, perioperative, chemotherapy, Western

\section{INTRODUCTION}

Recent evidence provided by clinical trials and modern technical developments have strongly facilitated the employment of a multimodal approach in gastric cancer treatment. Endoscopic resection is now accepted as a curative option for early gastric neoplastic lesions ${ }^{[1,2]}$. At the same time, laparoscopic gastrectomy has increased in popularity in recent years ${ }^{[3,4]}$. For locally advanced gastric cancer, radical gastrectomy with D2 lymph node dissection has become the standard surgery in most European high volume centers ${ }^{[5]}$. In addi-

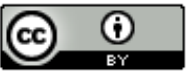

(C) The Author(s) 2018. Open Access This article is licensed under a Creative Commons Attribution 4.0 International License (https://creativecommons.org/licenses/by/4.0/), which permits unrestricted use, sharing, adaptation, distribution and reproduction in any medium or format, for any purpose, even commercially, as long as you give appropriate credit to the original author(s) and the source, provide a link to the Creative Commons license, and indicate if changes were made.

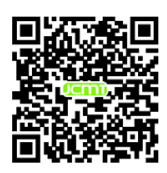




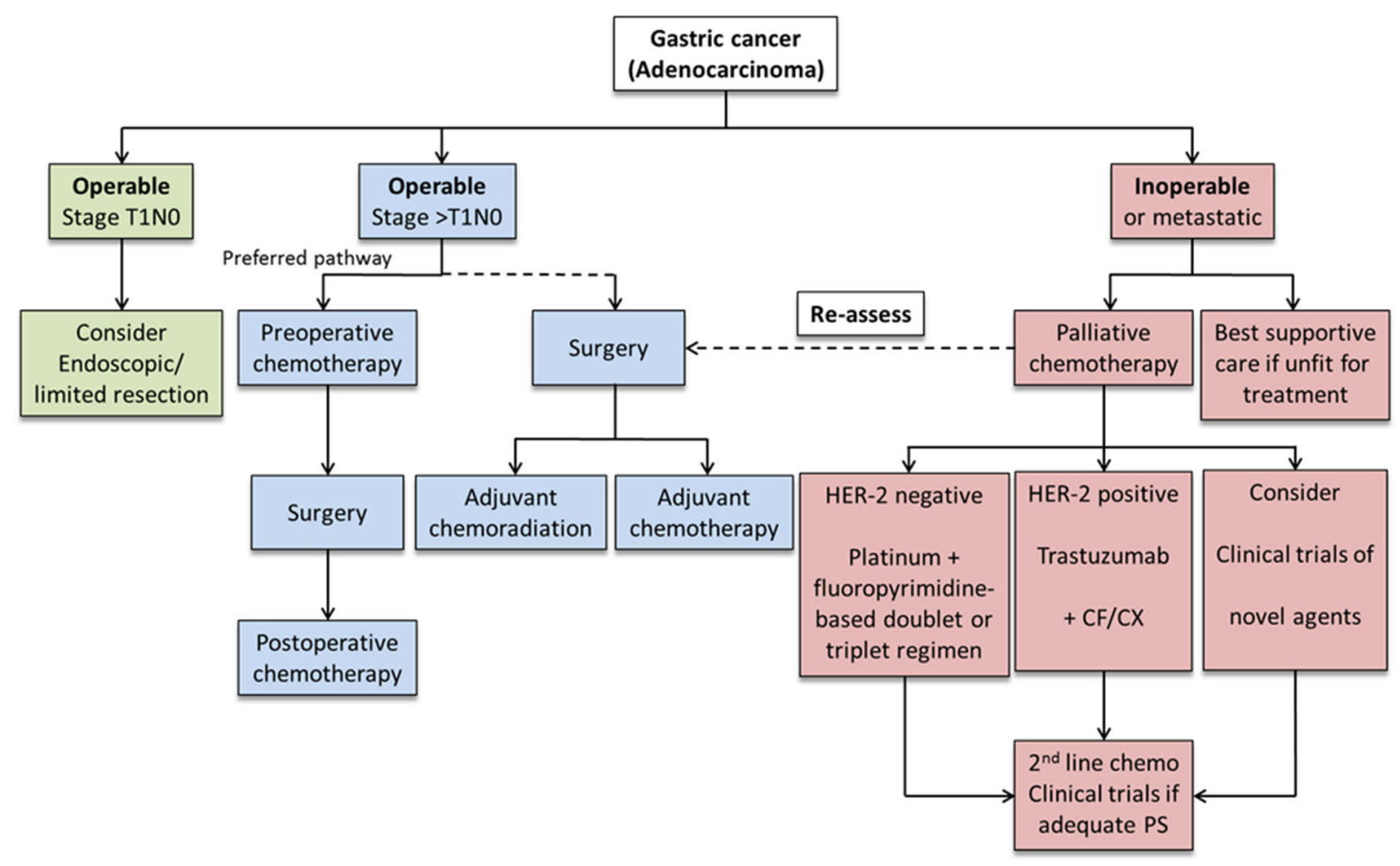

Figure 1. Algorithm for the management of gastric cancer in Europe ${ }^{[15]}$

tion, perioperative chemotherapy (CT) is the standard therapy in curatively intended disease in most European countries ${ }^{[6-10]}$, and also molecular targeted therapy has been implemented in human epidermal growth factor receptor (HER)-2 positive tumors in the palliative setting ${ }^{[11]}$. This review gives an overview of current surgical and perioperative management in curatively intended treatment for localized gastric cancer, as well as palliative management for metastatic disease, in Europe. Furthermore, we discuss recent therapeutic trends and future directions for gastric cancer management in a European setting.

\section{GASTRIC CANCER IN EUROPE}

There were 140,000 new cases of gastric cancer diagnosed across all European countries in $2012^{[12]}$. Gastric cancer is the sixth most common cancer and the fourth most common cause of cancer related death in Europe, causing 107,000 death annually. The treatment policy in Europe has lately, in several respects, been influenced by the Japanese Guidelines ${ }^{[13,14]}$ and this is reflected in most European professional organization guidelines such as those from ESMO/ESSO/ESTRO ${ }^{[15]}$. For planning treatment, ESMO/ESSO/ESTRO guidelines require multi-disciplinary team conferences including surgeons, medical oncologists, gastroenterologists, radiologists, pathologists, dieticians and nurse specialists. Figure 1 shows an algorithm for the management of gastric cancer in Europe.

Gastric cancers in the West tend to have a large proportion of the diffuse type histology, often located in the proximal stomach, compared to typical histology and tumor position in the East, which more commonly tend to be of the intestinal type and typically located in the distal stomach. Furthermore, gastric cancer in Europe is more likely to be diagnosed in advanced stages due to the low incidence and consequential lack of screening programs ${ }^{[16,17]}$. Consequently, due to the difference in disease characteristics, the proportion of total gastrectomies performed is substantially higher in Western treatment populations and studies. 
Table 1. Criteria for endoscopic submucosal dissection ${ }^{[19]}$

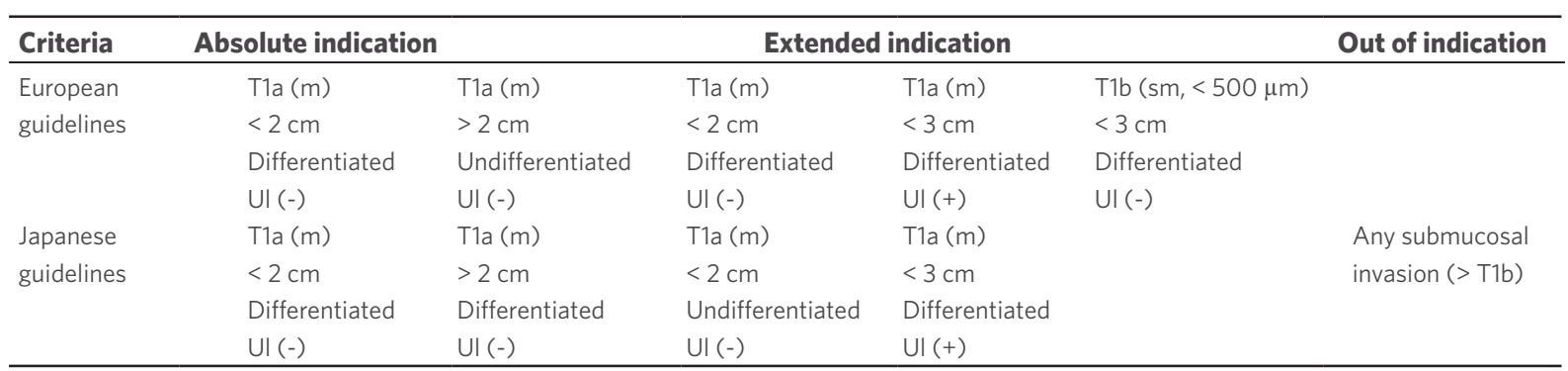

m: intramucosal; sm: submucosal; Ul: ulceration

\section{MANAGEMENT OF LOCAL/LOCOREGIONAL DISEASE}

\section{Endoscopic treatment}

Only around $10 \%-15 \%$ of gastric cancers in Europe are diagnosed as early gastric cancers. Although adoption of endoscopic submucosal dissection (ESD) in the West has been slow, due to a lower incidence of early gastric cancer, European Society of Gastrointestinal Endoscopy (ESGE) guidelines recommend ESD as the treatment of choice for most superficial neoplastic gastric lesions ${ }^{[18]}$. Guidelines from the National Cancer Center in Tokyo have expanded these criteria based on a large number of patients ${ }^{[2,19]}$. ESD should be considered for lesions with very low risk of lymph node metastasis, no matter if it meets the absolute or expanded indication criteria [Table 1]. Western studies have demonstrated an en-bloc and Ro resection rate of $98.4 \%$ and $90.2 \%$, respectively, which are comparable to corresponding results from Eastern Asian institutions ${ }^{[20]}$. The delayed bleeding rate was $6 \%$ and perforation rate was $1 \%$ which are also equivalent to Eastern Asian rates $^{[21-24]}$. The potential benefits of ESD are now acknowledged and ESD has become a promising treatment option, alongside conventional endoscopic mucosal resection (EMR), for early gastric cancer in Western countries.

\section{Surgical treatment}

Surgical resection remains the only treatment modality that is potentially curative for locally advanced gastric cancer. However, the extent of surgical resection and lymph node dissection is still, to some degree, controversial. Most European guidelines, nevertheless, recommend D2 dissection for stage II and III disease ${ }^{[15]}$. At the same time, minimally invasive gastrectomy is becoming more and more common ${ }^{[25]}$.

\section{Extent of gastric resection}

The extent of resection is basically determined by the tumor location as well as the tumor stage, the type and extension of stomach resection has a direct impact on patient's postoperative quality of life (QOL) ${ }^{[26,2]}$. In Western, in contrast to Far Eastern countries, most gastric cancers are diagnosed in the proximal stomach as locally advanced tumors, which subsequently usually require total gastrectomy with D2 lymph node dissection for optimized prognosis. Therefore, the number of suitable cases for function preserving surgical techniques, such as proximal and pylorus-preserving gastrectomy, which have been popularized in Eastern Asia due to advantages of improved postoperative QOL, are very few in European populations ${ }^{[28]}$. The vast majority of diagnosed European gastric cancer cases are instead more suitable for subtotal or total gastrectomy. Several studies have shown some functional advantages and comparable overall survival (OS) rate in subtotal gastrectomy compared with total gastrectomy ${ }^{[26,27,29,30]}$. ESMO/ESSO/ESTRO guidelines recommend macroscopic proximal margins of $5 \mathrm{~cm}$ between the proximal tumor margin and esophagogastric junction (EGJ) for subtotal or distal gastrectomy, and of $8 \mathrm{~cm}$ for the diffuse histological type of gastric cancer ${ }^{[15]}$. Nonetheless, some studies reported equivalence regarding oncological outcome with shorter proximal $\operatorname{margin}^{[31,32]}$. 


\section{Lymph node dissection}

Lymph node dissection is an important part of achieving local tumor control in gastric cancer treatment, and there has been much debate over the years on the optimal extent of this dissection. Traditionally, D2 lymph node dissection has been performed in Japan as standard practice since the 1960s, on the basis of excellent long-term outcomes in Japanese case series ${ }^{[13]}$. In Japan, D2 is the norm, while many surgeons in the West still prefer to perform D1 dissection. One of the reasons is the results of the well-known Dutch randomized clinical trial ${ }^{[33]}$, which compared the survival advantage of D2 lymph node dissection with D1 resection, failing to demonstrate any benefits in D2 group in the main overall survival analysis. However, in this trial the postoperative mortality was very high in the $\mathrm{D} 2 \mathrm{arm}$, which counterweighed any potential survival advantage of the extended lymph node dissection at 5 years follow-up. A stratified analysis showed that a large proportion of the morbidity and mortality in the $\mathrm{D} 2$ group was related to synchronous splenectomy and pancreatectomy while in the subgroup of patients without pancreaticosplenectomy the risk of relapse was significantly lower in the D2 compared to D1 group. However, in 10-year follow-up there was a significant advantage in overall survival for the D2 group ${ }^{[34]}$, despite the great losses in the early postoperative period. This and other publications showing excellent short term outcomes ${ }^{[35]}$ after D2 gastrectomy in Western high volume centres has led to the current Western consensus that D2 dissection should be the standard procedure if carried out in specialized, high-volume centers ${ }^{[5]}$.

\section{Laparoscopic gastrectomy}

Laparoscopic gastrectomy was launched in 1991 and the first laparoscopic total gastrectomy with D2 lymphadenectomy for advanced gastric cancer was reported in 2000 in Japan ${ }^{[36,37]}$. The clinical objective with this technique was to minimize the surgical access trauma while still providing the same oncological operation, in terms of T- and $\mathrm{N}$-radicality, as open gastrectomy. Advantages suggested and to some extent proven with laparoscopic gastrectomy, compared to open surgery, are less postoperative pain, earlier recovery of bowel function, shorter hospital stay and better cosmetic result ${ }^{[37-39]}$. Furthermore, the concern from sceptics regarding the efficacy of the laparoscopic lymphadenectomy, has been relieved, as the number of harvested lymph nodes has been shown to be comparable to that of open surgery ${ }^{[40]}$. Although laparoscopic distal gastrectomy for early gastric cancer is gradually accepted as an oncologically safe alternative to open gastrectomy in Europe, laparoscopic total gastrectomy and laparoscopic D2 lymph node dissection for advanced cases are still considered challenging, due to their technical nature. With respect to surgical and oncological safety, these procedures should be carefully implemented in experienced hands at centres with high annual caseloads.

\section{ADJUNCT THERAPY}

Many clinical phase III trials on adjunct therapy for gastric cancer have been conducted worldwide. Despite high-level evidence supporting the principle of adjuvant or neoadjuvant treatment, there is no standard of care for adjunct treatment in gastric cancer. Main landmark trials are summarized in Table 2. The two major studies of adjunctive therapy in western populations, the North American Intergroup INTo116 trial ${ }^{[41]}$, the MAGIC trial ${ }^{[42]}$, demonstrated two major directions, postoperative chemoradiotherapy (CRT) and perioperative CT. Through many clinical trials, new regimens such as FLOT $^{[43]}$, enhancement of preoperative treatment, and application of molecular targeted therapeutics are attracting much attention.

\section{Postoperative chemotherapy and chemoradiotherapy}

The INT0116 trial, the first randomized study evaluating the benefit of adjuvant $\mathrm{CRT}^{[41]}$, and a subsequent retrospective Dutch trial demonstrated that postoperative CRT improved OS and reduced local recurrence rates following D1 lymph node dissection or R1 resection ${ }^{[34]}$. Also the additional survival benefit of adjuvant CT has shown by Asian phase III ACTS-GC ${ }^{[44]}$ and CLASSIC trial ${ }^{[4]}$ in Asian patients. However, the ARTIST trial ${ }^{[46]}$, a phase III trial from Korea, and the recent Dutch CRITICS trial failed to show a survival advantage of postoperative additional radiation therapy to perioperative $\mathrm{CT}^{[47,48]}$. In the CRITICS trial, only $47 \%$ 
Table 2. Landmark trials of perioperative and palliative chemo/chemoradiotherapy in gastric cancer

\begin{tabular}{|c|c|c|c|c|}
\hline \multirow{3}{*}{$\begin{array}{l}\text { Study name (year)/ } \\
\text { region } \\
\text { INT-0116 }(2001)^{[41]} \\
\text { North America }\end{array}$} & \multirow{3}{*}{$\begin{array}{c}\text { Focus of trial } \\
\text { Adjuvant CRT }\end{array}$} & \multirow{2}{*}{$\begin{array}{l}\text { Treatment arms } \\
\text { Surgery alone }\end{array}$} & \multicolumn{2}{|c|}{ Main results $(95 \% \mathrm{Cl})$} \\
\hline & & & m-OS: 27 months & $\mathrm{HR}=1.35(1.09-1.66)$ \\
\hline & & & m-OS: 36 months & $P=0.005$ \\
\hline \multirow{2}{*}{$\begin{array}{l}\text { ACTS-GC }(2007)^{[44]} \\
\text { Japan }\end{array}$} & \multirow[t]{2}{*}{ Adjuvant CT } & Surgery alone & 3-OS: $70.1 \%$ & \multirow{2}{*}{$\begin{array}{l}\mathrm{HR}=0.68(0.52-0.87) \\
P=0.003\end{array}$} \\
\hline & & Suegery + S-1 & $3-\mathrm{OS}: 80.1 \%$ & \\
\hline \multirow{2}{*}{$\begin{array}{l}\text { CLASSIC }(2012)^{[45]} \\
\text { South Korea }\end{array}$} & \multirow[t]{2}{*}{ Adjuvant $\mathrm{CT}$} & Surgery alone & $3-$ OS: $59 \%$ & \multirow{2}{*}{$\begin{array}{l}\mathrm{HR}=0.56(0.44-0.72) \\
P<0.0001\end{array}$} \\
\hline & & Surgery + capecitabine/oxaliplatin & 3-OS: $74 \%$ & \\
\hline ARTIST $(2012)^{[46]}$ & \multirow[t]{2}{*}{ Adjuvant CRT } & Surgery (D2 resection) $+X P$ & 3-DFS: $74.2 \%$ & \multirow[t]{4}{*}{$P=0.086$} \\
\hline South Korea & & Surgery (D2 resection) $+\mathrm{XP} / \mathrm{RT}$ & 3-DFS: $78.2 \%$ & \\
\hline ARTIST-II ${ }^{[49]}$ & \multirow[t]{2}{*}{ Adjuvant CRT } & Surgery (D2 resection, node-positive) $+X P$ & \multirow{2}{*}{ In progress } & \\
\hline South Korea & & Surgery (D2 resection, node-positive) + XP/RT & & \\
\hline \multirow{2}{*}{$\begin{array}{l}\text { MAGIC }(2006)^{[42]} \\
\text { Europe }\end{array}$} & \multirow[t]{2}{*}{ Perioperative CT } & Surgery alone & 5-OS: $23 \%$ & \multirow{2}{*}{$\begin{array}{l}\mathrm{HR}=0.75(0.60-0.93) \\
P=0.009\end{array}$} \\
\hline & & $E C F+$ surgery $+E C F$ & 5-OS: $36 \%$ & \\
\hline \multirow{2}{*}{$\begin{array}{l}\text { FLOT }(2017)^{[54]} \\
\text { Germany }\end{array}$} & \multirow[t]{2}{*}{ Peiroperative CT } & $E C F$ or ECX + surgery $+E C F$ or ECX & m-OS: 35 months & \multirow{2}{*}{$\begin{array}{l}\mathrm{HR}=0.77(0.63-0.94) \\
P=0.012\end{array}$} \\
\hline & & FLOT + surgery + FLOT & m-OS: 50 months & \\
\hline \multirow{2}{*}{$\begin{array}{l}\text { CRITICS }(2011)^{[47,48]} \\
\text { The Netherlands }\end{array}$} & \multirow{2}{*}{$\begin{array}{l}\text { Perioperative } C T \\
\text { plus adjuvant } \mathrm{RT}\end{array}$} & $E C X$ or EOX + surgery $+X P / R T$ & 5-OS: $40.9 \%$ & \multirow[t]{2}{*}{$P=0.99$} \\
\hline & & $\mathrm{ECX}$ or EOX + surgery + ECX or EOX & 5-OS: $41.3 \%$ & \\
\hline \multirow{2}{*}{$\begin{array}{l}\text { POET }(2009)^{[55]} \\
\text { Germany }\end{array}$} & \multirow[t]{2}{*}{ Neoadjuvant CRT } & PLF + surgery & 3-OS: $27.7 \%$ & $H R=0.67(0.41-1.07)$ \\
\hline & & PLF/RT + surgery & $3-O S: 47.4 \%$ & $P=0.07$ \\
\hline TOPGEAR $(2017)^{[57]}$ & Perioperative CT & $E C F+$ surgery $+E C F$ & In progress & \\
\hline $\begin{array}{l}\text { Australia/New Zealand/ } \\
\text { Europe/Canada }\end{array}$ & $\begin{array}{l}\text { plus neoadujuvant } \\
\text { RT }\end{array}$ & $E C F / R T+$ surgery $+E C F$ & $\begin{array}{l}\text { Equivalent in gastroi } \\
\text { hematological } 50 \%\end{array}$ & $\begin{array}{l}\text { intestinal ( } 32 \% \text { vs. } 30 \%) \text { and } \\
\text { vs. } 52 \%) \text { toxicity }\end{array}$ \\
\hline MAGIC-B ${ }^{[59]}$ & Perioperative $\mathrm{CT}$ & $E C X+$ surgery $+E C X$ & In progress & \\
\hline & $\begin{array}{l}\text { plus molecular } \\
\text { targeted }\end{array}$ & $\begin{array}{l}\text { ECX/lapatinib or bevacizumab + surgery }+ \\
\text { ECX/lapatinib or bevacizumab }\end{array}$ & & \\
\hline INNOVATION (2016) ${ }^{[58]}$ & Perioperative CT & FP or XP & In progress & \\
\hline Europe & plus molecular & $\mathrm{FP}$ or $\mathrm{XP} /$ trastuzumab & & \\
\hline & & FP or XP/trastuzumab/pertuzumab & & \\
\hline$V-325(2006)^{[65]}$ & Palliative CT & FP & 2-OS: 9\% & Severe adverse event: $59 \%$ \\
\hline Europe & & DCF & 2-OS: $18 \%$ & Severe adverse event: $69 \%$ \\
\hline $\begin{array}{l}\text { REAL-2 (2008) })^{[51]} \\
\text { UK }\end{array}$ & Palliative $\mathrm{CT}$ & ECF $v s . \mathrm{ECX} v s$. EOF $v s . \mathrm{EOX}$ & $\begin{array}{l}\text { m-OS: } 9.9 \text { vs. } 9.9 \text { vs. } 9 \\
\text { 1-OS: } 37.7 \% \text { vs. } 40.8\end{array}$ & $\begin{array}{l}9.3 \text { vs. } 11.2 \text { months }(P=0.02) \\
3 \% \text { vs. } 40.4 \% \text { vs. } 46.8 \%\end{array}$ \\
\hline ML17032 (2009) $)^{[52]}$ & Palliative CT & $X P$ & m-OS: 10.5 months & $H R=0.85(0.64-1.13)$ \\
\hline South Korea & & $\mathrm{FP}$ & m-OS: 9.3 months & $P=0.008$ \\
\hline German AIO $(2011)^{[69]}$ & Palliative CT & $\mathrm{BSC}$ & m-OS: 2.4 months & Symptom improvement: $7 \%$ \\
\hline Germany & & Irinotecan & m-OS: 4.0 months & Symptom improvement: $50 \%$ \\
\hline COUGAR-02 $(2014)^{[70]}$ & Palliative $\mathrm{CT}$ & $\mathrm{BSC}$ & m-OS: 3.6 months & $H R=0.67(0.49-0.92)$ \\
\hline & & BSC/docetaxel & m-OS: 5.2 months & $P=0.01$ \\
\hline ToGA $(2010)^{[11]}$ & Palliative $\mathrm{CT}$ plus & $\mathrm{XP}$ or FP & m-OS: 11.1 months & $H R=0.74(0.60-0.91)$ \\
\hline South Korea & molecular targeted & $\mathrm{XP}$ or FP/trastuzumab & m-OS: 13.8 months & $P=0.005$ \\
\hline RAINBOW $(2014)^{[73]}$ & Palliative CT plus & Paclitaxel & m-OS: 7.4 months & $H R=0.81(0.68-0.96)$ \\
\hline Germany & molecular targeted & Paclitaxel/ramucirumab & m-OS: 9.6 months & $P=0.017$ \\
\hline REGARD $(2014)^{[74]}$ & Palliative molecular & BSC (placebo) & m-OS: 3.8 months & $H R=0.78(0.60-1.00)$ \\
\hline USA & targeted & Ramucirumab & m-OS: 5.2 months & $P=0.047$ \\
\hline ATTRACTION $(2017)^{[75]}$ & Palliative molecular & BSC (placebo) & m-OS: 4.1 months & $\mathrm{HR}=0.63(0.51-0.78)$ \\
\hline South Korea & targeted & Nivolumab & m-OS: 5.3 months & $P<0.0001$ \\
\hline
\end{tabular}

5-FU: fluorouracil; BSC: best supportive care; CRT: chemoradiotherapy; CT: chemotherapy; DCF: docetaxel/cisplatin/fluorouracil; DFS: disease free survival; ECF: epirubicin/cisplatin/fluorouracil; ECX: epirubicin/cisplatin/capecitabine; EOF: epirubicin/oxaliplatin/ fluorouracil; EOX: epirubicin/oxaliplatin/capecitabine; FLOT: fluorouracil/leucovorin/oxaliplatin/docetaxel; FP: fluorouracil/cisplatin; HR: hazard ratio; LV: leucovorin; m-OS: median overall survival; OS: overall survival; PLF: cisplatin/leucovorin/fluorouracil; RT: radiotherapy; XP: capecitabine/cisplatin

and $52 \%$ of patients completed postoperative CT and CRT therapy, to a large extent due to low postoperative treatment tolerance in Western patients. This study suggested that Western adjunct treatment should shift to 
preoperative strategies, considering patients' tolerability for treatment. The subsequent ARTIST-II trial which focused on adjuvant CRT for node-positive patients ${ }^{[49]}$ and CRIRTICS-II trial to evaluate the significance of preoperative CRT strategies for curative gastric cancer are now in progress.

\section{Perioperative chemotherapy}

In general, prior to surgery, patients usually tolerate adjunct treatment rather well, perhaps due to an intact performance status. Neoadjuvant chemotherapy has not been shown to increase postoperative morbidity or mortality, while neoadjuvant chemoradiotherapy may be associated to increased morbidity, at least for junctional tumors ${ }^{[50]}$. On this basis, all guidelines recommend this type of down-staging treatment for patients with locally advanced gastric cancer and perioperative therapy has therefore been widely adopted as the standard of care throughout Europe. The MAGIC trial was the first to provide the perioperative therapeutic option for resectable gastric cancer with favorable results of perioperative CT compared with surgery alone ${ }^{[42]}$. However, the epirubicin, cisplatin and fluorouracil (ECF) protocol used in the MAGIC trial has requirements that limit its use in non-trial situations (e.g., the need for a central line and constant specialized handling) and poor postoperative completion rates (42\%). The REAL-2 trial showed that the ECF and epirubicin, oxaliplatin, and capecitabine (EOX) regimens were equally effective for advanced tumors, whereas a meta-analysis of the data from the REAL-2 and ML17032 trials suggested better response rates and OS with capecitabine combinations ${ }^{[51-53]}$. EOX regimen is now widely accepted as adjunct treatment in the West.

The recent FLOT4-AIO trial offered a new option with favorable results for locally advanced gastric can$\operatorname{cer}^{[43]}$. In this trial, 716 patients who had clinical stage $\mathrm{T} 2$ or higher and/or nodal positive disease were randomly assigned to either three pre- and postoperative cycles of epirubicin, cisplatin and either infusion of fluorouracil (5-FU) or capecitabine (ECF/ECX group) or four pre-and postoperative cycles of 5-FU/leucovorin, docetaxel and oxaliplatin (FLOT group). Thirty-five percent of patients in the FLOT group had at least one serious adverse event involving a perioperative medical or surgical complication and $51 \%$ had grade 3-4 neutropenia, which was higher than 39\% in ECF/ECX group. Overall 5-year survival was $45 \%$ in FLOT group, significantly better than the $36 \%$ in ECX/ECF group with a hazard ratio (HR) of 0.77 (95\% confidence interval $0.63-0.94)^{[54]}$. FLOT type perioperative chemotherapy can now be considered the Western gold standard regimen in the treatment of locally advanced, non-metastatic gastric cancer.

A number of new clinical trials are in progress to investigate new neoadjuvant and adjuvant regimens to further improve outcomes. The reinforcement of preoperative treatment is one possible future direction. The German POET trial, which aimed to clarify the impact of additional preoperative radiotherapy to neoadjuvant CT for patients with EGJ adenocarcinoma, demonstrated a non-statistically significant improved median survival compared to the CT-alone group ${ }^{[55]}$. However, it showed a substantially higher rate of pathological complete response ${ }^{[56]}$, in the CRT group ( $15.6 \%$ vs. $2.0 \%$ ). These results emphasized the importance of strengthening the preoperative therapy, and thus neoadjuvant CRT has been suggested to be effective and beneficial. The TOPGEAR trial is currently evaluating the impact of additional preoperative radiotherapy to perioperative $\mathrm{CT}^{[57]}$.

Another option for improving surgical outcomes is molecular targeted therapy, which has been demonstrated in the palliative setting. Some molecular targeted agents, such as trastuzumab and lapatinib, are being introduced into perioperative use. The INNOVATION trial, a 3-arm randomized phase II trial evaluating if neoadjuvant dual HER-2 blockade with CT, may lead to higher pathologic complete response rates than trastuzumab and CT, or CT alone, in resectable gastric cancer ${ }^{[58]}$. The MAGIC-B trial is also investigating the additional tyrosine kinase inhibitor lapatinib to perioperative ECX in the subset of the patients with HER2 overexpressing tumors ${ }^{[59]}$. These new studies are expected to provide new, molecularly tailored treatment options. 


\section{EUROPEAN TRENDS IN THE MANAGEMENT OF ADVANCED/METASTATIC GASTRIC CANCER}

The aim of palliative CT is to increase survival and palliate the clinical symptoms of the disease, with as little toxicity and negative impact on QOL as possible. Available data from randomized clinical trials clearly show a statistically significant advantage of palliative CT, compared with best supportive care $(B S C)^{[60]}$. To improve the efficacy and to reduce the adverse effects of CT, optimal agents and combinations are currently being sought.

\section{First line}

Historically, doublet regimens using platinum and fluoropyrimidine have been frequently used in palliative setting. Alternative to platinum/ fluoropyrimidine doublet regimen, taxane-based regimen and irinotecan plus 5-FU are suggested ${ }^{[61]}$. Irinotecan and oxaliplatin have shown better tolerability and equivalent time-toprogression in comparison to cisplatin, and guidelines suggest that these agents are promising substitutes for cisplatin in combination with fluoropyrimidines as well as capecitabine for 5-FU within doublet and triplet regimen ${ }^{[53,62,63]}$.

A meta-analysis demonstrated that adding anthracycline to platinum and fluoropyrimidine doublet significantly improved survival ${ }^{[64]}$. Additional docetaxel to 5-FU/CDDP (DCF) is another option to strengthen the CT but careful use is necessary in the palliative setting, due to low margins to toxicity. The V-325 trial and FLOT trial showed the advantage of additional therapeutic effects by taxane-based triplet regimen ${ }^{[65,66]}$. Although DCF in V-325 trial was superior to CF in response rate (RR) (37\% vs. 25\%), time-to-progression (5.6 vs. 3.7 months) and 2-year survival rate ( $18 \% v s .9 \%)$, the absolute benefit in terms of survival was less than 4 weeks and was counterbalanced by a significant high 3-4 adverse events rate. Similarly, FLOT regimen showed improved response rate ( $49 \%$ vs. $28 \%$ ), better progression free survival (PFS) ( 9.0 vs. 7.1 months, $P=$ $0.79)$ and no significant benefit in median OS (17.3 vs. 14.5 months, $P=0.39)$. Although there were no differences in serious adverse events, QOL was worse in FLOT group.

These triplet regimens have not demonstrated convincing benefits in terms of survival, but instead increased toxicity rates. Therefore, these regimens are not generally accepted in the palliative setting, so far. The clinical question of which subgroups may be suitable for the stronger triplet regimens, for locally advanced or metastatic disease, is currently under investigation.

\section{Second line and more}

ESMO/ESSO/ESTRO Guidelines recommend the use of irinotecan, docetaxel and paclitaxel as second line therapy, since these agents have shown to improve OS and QOL compared to BSC in patients with a good performance status ${ }^{[67]}$. The European guidelines also stress the fact that both paclitaxel and irinotecan have been directly compared in a Japanese Phase III trial showing similar efficacy in median OS for 8 to 9 months ${ }^{[68]}$. The German AIO phase III study demonstrated superiority of irinotecan compared to BSC in terms of improvement in tumor-related symptoms as second line therapy ${ }^{[69]}$. The COUGAR-02 trial confirmed that docetaxel achieved a significant benefit in OS $(5.2 v s .3 .6$ months, $P=0.01)$ in patients with a performance status of $0-2$ after failure of fluoropyrimidine/platinum regimen ${ }^{[70]}$. In spite of the fact that $21 \%$ of patients treated with docetaxel experienced grade 4 toxicities, significantly less pain and a trend towards less dysphagia and nausea, were reported. Based on the results of these well conducted randomized trials, a benefit of irinotecan and docetaxel as second-line treatment was clearly established for patients with good performance status. These treatment options should be offered with close monitoring of potential adverse effects.

\section{Palliative radiation therapy}

Guidelines mention that hypo-fractionated radiotherapy is an effective and well-tolerated treatment option for symptomatic locally advanced or recurrent disease ${ }^{[71]}$. In non-comparative observational studies, the 
overall response rates for bleeding, pain and obstruction symptoms were $74 \%, 67 \%$ and $68 \%$ respectively, low biological equivalent dose of $>39$ Gy regimens appear to be adequate for symptom palliation ${ }^{[72]}$.

\section{TARGETED THERAPIES}

As in other solid organ tumors, the biological abnormalities triggering the development and progression of gastric cancer are increasingly elucidated through ongoing research. These findings have potentially important implications as investigators attempt to elucidate the key pathways driving the tumor in each individual patient.

Overexpression of the HER2 gene, which is present in approximately $10 \%-20 \%$ of gastric cancers, is more common in intestinal type than diffuse type gastric cancer and more common in EGJ cancer than distal gastric cancer. Following the phase III ToGA trial, which demonstrated statistically significant improvement in PFS and OS with the addition of trastuzumab to a cisplatin/5-FU doublet regimen, trastuzumab was licensed in Europe for use in HER-2 positive disease in combination with capecitabine or 5-FU and cisplatin doublet ${ }^{[11]}$. This regimen currently represents the standard of care for these palliative patients. Also, the large phase III RAINBOW trial and REGARD trial, have shown the survival benefit of ramucirumab, a monoclonal antibody VEGFR-2 antagonist, as second line in the palliative setting ${ }^{[73,74]}$. Moreover, nivolumab, a fully human IgG4 monoclonal antibody inhibitor of programmed death-1, significantly improved the median overall survival in patients with advanced gastric cancer, or gastro-esophageal junction cancer, who had been previously treated with two or more chemotherapy regimens (ATTRACTION-2 trial) ${ }^{[75]}$. Several studies targeting HER2, VEGF, EGFR, T-DM1 are currently ongoing with some potentially favorable results ${ }^{[76-80]}$. Further developments in molecular subtyping of gastric cancer are likely to offer new possibilities in personalized treatment of gastric cancer in the future ${ }^{[81-84]}$.

\section{CONCLUSION}

It is clear that the multimodal therapy encompassing both radical surgical treatment and perioperative CT/ CRT offers the best possibility to cure resectable gastric cancer. In Western countries, minimally invasive approaches and D2 dissection have been successfully implemented at some high-volume centers. However, these procedures are still not standardized in the whole population-based case-load of incident cases, due to the low incidence of gastric cancer in Europe and other Western populations. Although the prospective clinical trials performed have achieved clear improvements in the therapeutic outcomes and patients' prognosis in the last decades, an optimal treatment for advanced gastric cancer has not been established, given the still poor overall survival. Recent advances in molecular tumor biology of adenocarcinoma of the stomach offer us important clues about future tailoring of gastric cancer treatment. Furthermore the rapid developments in sequencing techniques are likely to revolutionize our understanding of disease biology in the next decades. It is very likely that a number of new biomarkers will provide completely new options for personalized therapy, which may realize substantial therapeutic improvements, with excellent efficacy and tolerable adverse effects.

\section{DECLARATIONS}

\section{Authors' contributions}

Designed the study, reviewed the literature, and wrote the manuscript: Kamiya S

Contributed to writing the manuscript, drafting, critical revision, editing, and final approval of the final version: Nilsson M

Contributed to critical reversion of the manuscript and final approval of the final version: Rouvelas I, Lindblad M

\section{Availability of data and materials}

Not applicable. 


\section{Financial support and sponsorship}

None.

\section{Conflicts of interest}

All authors declare that there are no conflicts of interest.

\section{Ethical approval and consent to participate}

Not applicable.

\section{Consent for publication}

Not applicable.

\section{Copyright}

(c) The Author(s) 2018.

\section{REFERENCES}

1. Tada M, Tanaka Y, Matsuo N, Shimamura T, Yamaguchi K. Mucosectomy for gastric cancer: current status in Japan. J Gastroenterol Hepatol 2000;15 Suppl:D98-102.

2. Gotoda T, Iwasaki M, Kusano C, Seewald S, Oda I. Endoscopic resection of early gastric cancer treated by guideline and expanded National Cancer Centre criteria. Br J Surg 2010;97:868-71.

3. Memon MA, Khan S, Yunus RM, Barr R, Memon B. Meta-analysis of laparoscopic and open distal gastrectomy for gastric carcinoma. Surg Endosc 2008;22:1781-9.

4. Haverkamp L, Weijs TJ, van der Sluis PC, van der Tweel I, Ruurda JP, van Hillegersberg R. Laparoscopic total gastrectomy versus open total gastrectomy for cancer: a systematic review and meta-analysis. Surg Endosc 2013;27:1509-20.

5. Dikken JL, van Sandick JW, Allum WH, Johansson J, Jensen LS, Putter H, Coupland VH, Wouters MW, Lemmens VE, van de Velde CJ, van der Geest LG, Larsson HJ, Cats A, Verheij M. Differences in outcomes of oesophageal and gastric cancer surgery across Europe. Br J Surg 2013;100:83-94.

6. Choi AH, Kim J, Chao J. Perioperative chemotherapy for resectable gastric cancer: MAGIC and beyond. World J Gastroenterol 2015;21:7343-8.

7. Marano L, Polom K, Patriti A, Roviello G, Falco G, Stracqualursi A, De Luca R, Petrioli R, Martinotti M, Generali D, Marrelli D, Di Martino N, Roviello F. Surgical management of advanced gastric cancer: an evolving issue. Eur J Surg Oncol 2016;42:18-27.

8. Merrett ND. Multimodality treatment of potentially curative gastric cancer: geographical variations and future prospects. World J Gastroenterol 2014;20:12892-9.

9. Samalin E, Ychou M. Neoadjuvant therapy for gastroesophageal adenocarcinoma. World J Clin Oncol 2016;7:284-92.

10. Foo M, Leong T. Adjuvant therapy for gastric cancer: current and future directions. World J Gastroenterol 2014;20:13718-27.

11. Bang YJ, Van Cutsem E, Feyereislova A, Chung HC, Shen L, Sawaki A, Lordick F, Ohtsu A, Omuro Y, Satoh T, Aprile G, Kulikov E, Hill J, Lehle M, Rüschoff J, Kang YK. Trastuzumab in combination with chemotherapy versus chemotherapy alone for treatment of HER2-positive advanced gastric or gastro-oesophageal junction cancer (ToGA): a phase 3, open-label, randomized controlled trial. Lancet 2010;376:68797.

12. Ferlay J, Steliarova-Foucher E, Lortet-Tieulent J, Rosso S, Coebergh JW, Comber H, Forman D, Bray F. Cancer incidence and mortality patterns in Europe: estimates for 40 countries in 2012. Eur J Cancer 2013;49:1374-403.

13. Japanese Gastric Cancer Association. Japanese gastric cancer treatment guidelines 2014 (ver. 4). Gastric Cancer 2017;20:1-19.

14. Japanese Gastric Cancer Association. Japanese classification of gastric carcinoma: 3rd English edition. Gastric Cancer 2011;14:101-12.

15. Waddell T, Verheij M, Allum W, Cunningham D, Cervantes A, Arnold D; European Society for Medical Oncology (ESMO); European Society of Surgical Oncology (ESSO); European Society of Radiotherapy and Oncology (ESTRO). Gastric cancer: ESMO-ESSO-ESTRO clinical practice guidelines for diagnosis, treatment and follow-up. Eur J Surg Oncol 2014;40:584-91.

16. World Health Organization. GLOBOCAN 2012: estimated cancer incidence, mortality and prevalence worldwide 2012.

17. Karimi P, Islami F, Anandasabapathy S, Freedman ND, Kamangar F. Gastric cancer: descriptive epidemiology, risk factors, screening, and prevention. Cancer Epidemiol Biomark Prev 2014;23:700-13.

18. Pimentel-Nunes P, Dinis-Ribeiro M, Ponchon T, Repici A, Vieth M, De Ceglie A, Amato A, Berr F, Bhandari P, Bialek A, Conio M, Haringsma J, Langner C, Meisner S, Messmann H, Morino M, Neuhaus H, Piessevaux H, Rugge M, Saunders BP, Robaszkiewicz M, Seewald S, Kashin S, Dumonceau JM, Hassan C, Deprez PH. Endoscopic submucosal dissection: European Society of Gastrointestinal Endoscopy (ESGE) Guideline. Endoscopy 2015;47:829-54.

19. Ono H, Yao K, Fujishiro M, Oda I, Nimura S, Yahagi N, Iishi H, Oka M, Ajioka Y Ichinose M, Matsui T. Guidelines for endoscopic submucosal dissection and endoscopic mucosal resection for early gastric cancer. Dig Endosc 2016;28:3-15.

20. Probst A, Schneider A, Schaller T, Anthuber M, Ebigbo A, Messmann H. Endoscopic submucosal dissection for early gastric cancer: are expanded resection criteria safe for Western patients? Endoscopy 2017;49:855-65.

21. Ahn JY, Jung HY, Choi KD, Choi JY, Kim MY, Lee JH, Choi KS, Kim DH, Song HJ, Lee GH, Kim JH, Park YS. Endoscopic and oncologic 
outcomes after endoscopic resection for early gastric cancer: 1370 cases of absolute and extended indications. Gastrointest Endosc 2011;74:485-93.

22. Park CH, Shin S, Park JC, Shin SK, Lee SK, Lee YC, Lee H. Long-term outcome of early gastric cancer after endoscopic submucosal dissection: expanded indication is comparable to absolute indication. Dig Liver Dis 2013;45:651-6.

23. Hotta K, Oyama T, Akamatsu T, Tomori A, Hasebe O, Nakamura N, Kojima E, Suga T, Miyabayashi H, Ohta H. A comparison of outcomes of endoscopic submucosal dissection (ESD) for early gastric neoplasms between high-volume and low-volume centers: multi-center retrospective questionnaire study conducted by the Nagano ESD Study Group. Intern Med 2010;49:253-9.

24. Oda I, Saito D, Tada M, Iishi H, Tanabe S, Oyama T, Doi T, Otani Y, Fujisaki J, Ajioka Y, Hamada T, Inoue H, Gotoda T, Yoshida S. A multicenter retrospective study of endoscopic resection for early gastric cancer. Gastric Cancer 2006;9:262-70.

25. van der Wielen N, Straatman J, Cuesta MA, Daams F, van der Peet DL. Short-term outcomes in minimally invasive versus open gastrectomy: the differences between East and West. A systematic review of the literature. Gastric Cancer 2018;21:19-30.

26. Park S, Chung HY, Lee SS, Kwon O, Yu W. Serial comparisons of quality of life after distal subtotal or total gastrectomy: what are the rational approaches for quality of life management? J Gastric Cancer 2014;14:32-8.

27. Davies J, Johnston D, Sue-Ling H, Young S, May J, Griffith J, Miller G, Martin I.Total or subtotal gastrectomy for gastric carcinoma? A study of quality of life. World J Surg 1998;22:1048-55.

28. Hiki N, Nunobe S, Kubota T, Jiang X. Function-preserving gastrectomy for early gastric cancer. Ann Surg Oncol 2013;20:2683-92.

29. Kosuga T, Hiki N, Nunobe S, Noma H, Honda M, Tanimura S, Sano T, Yamaguchi T. Feasibility and nutritional impact of laparoscopyassisted subtotal gastrectomy for early gastric cancer in the upper stomach. Ann Surg Oncol 2014;21:2028-35.

30. Jiang X, Hiki N, Nunobe S, Nohara K, Kumagai K, Sano T, Yamaguchi T. Laparoscopy-assisted subtotal gastrectomy with very small remnant stomach: a novel surgical procedure for selected early gastric cancer in the upper stomach. Gastric Cancer 2011;14:194-9.

31. Postlewait LM, Squires MH 3rd, Kooby DA, Poultsides GA, Weber SM, Bloomston M, Fields RC, Pawlik TM, Votanopoulos KI, Schmidt CR, Ejaz A, Acher AW, Worhunsky DJ, Saunders N, Swords D, Jin LX, Cho CS, Winslow ER, Cardona K, Staley CA, Maithel SK. The importance of the proximal resection margin distance for proximal gastric adenocarcinoma: a multi-institutional study of the US Gastric Cancer Collaborative. J Surg Oncol 2015;112:203-7.

32. Numata N, Oka S, Tanaka S, Kagemoto K, Sanomura Y, Yoshida S, Arihiro K, Shimamoto F, Chayama K. Risk factors and management of positive horizontal margin in early gastric cancer resected by en bloc endoscopic submucosal dissection. Gastric Cancer 2015;18:332-8.

33. Hartgrink HH, van de Velde CJ, Putter H, Bonenkamp JJ, Klein Kranenbarg E, Songun I, Welvaart K, van Krieken JH, Meijer S, Plukker JT, van Elk PJ, Obertop H, Gouma DJ, van Lanschot JJ, Taat CW, de Graaf PW, von Meyenfeldt MF, Tilanus H, Sasako M. Extended lymph node dissection for gastric cancer: who may benefit? Final results of the randomized Dutch gastric cancer group trial. J Clin Oncol 2004;22:2069-77.

34. Songun I, Putter H, Kranenbarg EM, Sasako M, van de Velde CJ. Surgical treatment of gastric cancer: 15-year follow-up results of the randomised nationwide Dutch D1D2 trial. Lancet Oncol 2010;11:439-49.

35. Kung CH, Lindblad M, Nilsson M, Rouvelas I, Kumagai K, Lundell L, Tsai JA. Postoperative pancreatic fistula formation according to ISGPF criteria after D2 gastrectomy in Western patients. Gastric Cancer 2014;17:571-7.

36. Uyama I, Sugioka A, Matsui H, Fujita J, Komori Y, Hasumi A. Laparoscopic D2 lymph node dissection for advanced gastric cancer located in the middle or lower third portion of the stomach. Gastric Cancer 2000;3:50-5.

37. Kitano S, Shiraishi N, Fujii K, Yasuda K, Inomata M, Adachi Y. A randomized controlled trial comparing open vs laparoscopy-assisted distal gastrectomy for the treatment of early gastric cancer: an interim report. Surgery 2002;131:S306-11.

38. Lee JH, Han HS, Lee JH. A prospective randomized study comparing open vs laparoscopy-assisted distal gastrectomy in early gastric cancer: early results. Surg Endosc 2005;19:168-73.

39. Kim HH, Hyung WJ, Cho GS, Kim MC, Han SU, Kim W, Ryu SW, Lee HJ, Song KY. Morbidity and mortality of laparoscopic gastrectomy versus open gastrectomy for gastric cancer: an interim report--a phase III multicenter, prospective, randomized trial (KLASS Trial). Ann Surg 2010;251:417-20.

40. Zou ZH, Zhao LY, Mou TY, Hu YF, Yu J, Liu H, Chen H, Wu JM, An SL, Li GX. Laparoscopic vs open D2 gastrec- tomy for locally advanced gastric cancer: a meta-analysis. World J Gastroenterol 2014;20:16750-64.

41. Macdonald JS, Smalley SR, Benedetti J, Hundahl SA, Estes NC, Stemmermann GN, Haller DG, Ajani JA, Gunderson LL, Jessup JM, Martenson JA. Chemoradiotherapy after surgery compared with surgery alone for adenocarcinoma of the stomach or gastroesophageal junction. N Engl J Med 2001;345:725-30.

42. Cunningham D, Allum WH, Stenning SP, Thompson JN, Van de Velde CJ, Nicolson M, Scarffe JH, Lofts FJ, Falk SJ, Iveson TJ, Smith DB, Langley RE, Verma M, Weeden S, Chua YJ. Perioperative chemotherapy versus surgery alone for resectable gastroesophageal cancer. $\mathrm{N}$ Engl J Med 2006;355:11-20.

43. Al-Batran SE, Hofheinz RD, Pauligk C, Kopp HG, Haag GM, Luley KB, Meiler J, Homann N, Lorenzen S, Schmalenberg H, Probst S, Koenigsmann M, Egger M, Prasnikar N, Caca K, Trojan J, Martens UM, Block A, Fischbach W, Mahlberg R, Clemens M, Illerhaus G, Zirlik K, Behringer DM, Schmiegel W, Pohl M, Heike M, Ronellenfitsch U, Schuler M, Bechstein WO, Königsrainer A, Gaiser T, Schirmacher P, Hozaeel W, Reichart A, Goetze TO, Sievert M, Jäger E, Mönig S, Tannapfel A. Histopathological regression after neoadjuvant docetaxel, oxaliplatin, fluorouracil, and leucovorin versus epirubicin, cisplatin, and fluorouracil or capecitabine in patients with resectable gastric or gastro-oesophageal junction adenocarcinoma (FLOT4-AIO): results from the phase 2 part of a multicentre, open-label, randomised phase 2/3 trial. Lancet Oncol 2016;17:1697-708.

44. Sakuramoto S, Sasako M, Yamaguchi T, Kinoshita T, Fujii M, Nashimoto A, Furukawa H, Nakajima T, Ohashi Y, Imamura H, Higashino M, Yamamura Y, Kurita A, Arai K; ACTS-GC Group. Adjuvant chemotherapy for gastric cancer with S-1, an oral fluoropyrimidine. N Engl J Med 2007;357:1810-20.

45. Bang YJ, Kim YW, Yang HK, Chung HC, Park YK, Lee KH, Lee KW, Kim YH, Noh SI, Cho JY, Mok YJ, Kim YH, Ji J, Yeh TS, Button P, Sirzen F, Noh SH; CLASSIC trial investigators. Adjuvant capecitabine and oxaliplatin for gastric cancer after D2 gastrectomy (CLASSIC): 
a phase 3 open-label, randomised controlled trial. Lancet 2012;379:315-21.

46. Lee J, Lim do H, Kim S, Park SH, Park JO, Park YS, Lim HY, Choi MG, Sohn TS, Noh JH, Bae JM, Ahn YC, Sohn I, Jung SH, Park CK, Kim KM, Kang WK. Phase III trial comparing capecitabine plus cisplatin versus capecitabine plus cisplatin with concurrent capecitabine radiotherapy in completely resected gastric cancer with D2 lymph node dissection: the ARTIST trial. J Clin Oncol 2012;30:268-73.

47. Dikken JL, van Sandick JW, Maurits Swellengrebel HA, Lind PA, Putter H, Jansen EP, Boot H, van Grieken NC, van de Velde CJ, Verheij M, Cats A. Neoadjuvant chemotherapy followed by surgery and chemotherapy or by surgery and chemoradiotherapy for patients with resectable gastric cancer (CRITICS). BMC Cancer 2011;11:329.

48. Verheij M, Jansen EPM, Cats A, van Grieken NCT, Aaronson NK, Boot H. A multicenter randomized phase III trial of neo-adjuvant chemotherapy followed by surgery and chemotherapy or by surgery and chemoradiotherapy in resectable gastric cancer: First results from the CRITICS study. J Clin Oncol 2016;34 suppl 15:abstr4000.

49. Phase III Randomized Trial of Adjuvant Chemotherapy With S-1 vs S-1/Oxaliplatin \pm Radiotherapy for Completely Resected Gastric Adenocarcinoma: The ARTIST II Trial (ARTIST-II). ClinicalTrials.gov Identifier: NCT01761461.

50. Kumagai K, Rouvelas I, Tsai JA, Mariosa D, Klevebro F, Lindblad M, Ye W, Lundell L, Nilsson M. Meta-analysis of postoperative morbidity and perioperative mortality in patients receiving neoadjuvant chemotherapy or chemoradiotherapy for resectable oesophageal and gastro-oesophageal junctional cancers. Br J Surg 2014;101:321-38.

51. Cunningham D, Starling N, Rao S, Iveson T, Nicolson M, Coxon F, Middleton G, Daniel F, Oates J, Norman AR. Capecitabine and oxaliplatin for advanced esophagogastric cancer. N Engl J Med 2008;358:36-46.

52. Ryu MH, Kang YK. ML17032 trial: capecitabine/cisplatin versus 5-fluorouracil/cisplatin as first-line therapy in advanced gastric cancer. Expert Rev Anticancer Ther 2009;9:1745-51.

53. Okines AF, Norman AR, McCloud P, Kang YK, Cunningham D. Meta-analysis of the REAL-2 and ML17032 trials: evaluating capecitabine-based combination chemotherapy and infused 5-fluorouracil-based combination chemotherapy for the treatment of advanced oesophago-gastric cancer. Ann Oncol 2009;20:1529-34.

54. Al-Batran SE, Homann N, Schmalenberg H, Kopp HG, Haag GM, Luley KB, Schmiegel WH, Folprecht G, Probst S, Prasnikar N, ThussPatience P, Fischbach W, Trojan J, Koenigsmann M, Pauligk C, Goetze TO, Jaeger E, Meiler J, Schuler M, Hofheinz R. Perioperative chemotherapy with docetaxel, oxaliplatin, and fluorouracil/leucovorin (FLOT) versus epirubicin, cisplatin, and fluorouracil or capecitabine (ECF/ECX) for resectable gastric or gastroesophageal junction (GEJ) adenocarcinoma (FLOT4-AIO): a multicenter, randomized phase 3 trial. J Clin Oncol 2017;35 suppl:abstr 4004.

55. Stahl M, Walz MK, Stuschke M, Lehmann N, Meyer HJ, Riera-Knorrenschild J, Langer P, Engenhart-Cabillic R, Bitzer M, Königsrainer A, Budach W, Wilke H. Phase III comparison of preoperative chemotherapy compared with chemoradiotherapy in patients with locally advanced adenocarcinoma of the esophagogastric junction. J Clin Oncol 2009;27:851-6.

56. Chirieac LR, Swisher SG, Ajani JA, Komaki RR, Correa AM, Morris JS, Roth JA, Rashid A, Hamilton SR, Wu TT. Posttherapy pathologic stage predicts survival in patients with esophageal carcinoma receiving preoperative chemoradiation. Cancer 2005;103:1347-55.

57. Leong T, Smithers BM, Haustermans K, Michael M, Gebski V, Miller D, Zalcberg J, Boussioutas A, Findlay M, O’Connell RL, Verghis J, Willis D, Kron T, Crain M, Murray WK, Lordick F, Swallow C, Darling G, Simes J, Wong R. TOPGEAR: a randomized, phase III trial of perioperative ECF chemotherapy with or without preoperative chemoradiation for resectable gastric cancer: interim results from an international, intergroup trial of the AGITG, TROG, EORTC and CCTG. Ann Surg Oncol 2017;24:2252-8.

58. European Organisation for Research and Treatment of Cancer - EORTC. Integration of trastuzumab, with or without pertuzumab, into perioperative chemotherapy of HER2- positive stomach cancer: the INNOVATION trial (EORTC-1203-GITCG). Oncol Res Treat 2016;39:153-4; discussion 155 .

59. Cunningham D. A randomised phase II/III trial of peri-operative chemotherapy with or without bevacizumab in operable oesophagogastric adenocarcinoma and a feasibility study evaluating lapatinib in HER-2 positive oesophagogastric adenocarcinomas and (in selected centres) MRI and PET/CT sub-studies. Available from: http:/ichgcp.net/clinical-trials-registry/NCT00450203 [Last accessed on 6 Jul 2018].

60. Wagner AD, Grothe W, Haerting J, Kleber G, Grothey A, Fleig WE. Chemotherapy in advanced gastric cancer: a systematic review and meta-analysis based on aggregate data. J Clin Oncol 2006;24:2903-9.

61. Dank M, Zaluski J, Barone C, Valvere V, Yalcin S, Peschel C, Wenczl M, Goker E, Cisar L, Wang K, Bugat R. Randomized phase III study comparing irinotecan combined with 5-fluorouracil and folinic acid to cisplatin combined with 5-fluorouracil in chemotherapy naive patients with advanced adenocarcinoma of the stomach or esophagogastric junction. Ann Oncol 2008;19:1450-7.

62. Moehler M, Kanzler S, Geissler M, Raedle J, Ebert MP, Daum S, Flieger D, Seufferlein T, Galle PR, Hoehler T. A randomized multicenter phase II study comparing capecitabine with irinotecan or cisplatin in metastatic adenocarcinoma of the stomach or esophagogastric junction. Ann Oncol 2010;21:71-7.

63. Kang YK, Kang WK, Shin DB, Chen J, Xiong J, Wang J, Lichinitser M, Guan Z, Khasanov R, Zheng L, Philco-Salas M, Suarez T, Santamaria J, Forster G, McCloud PI. Capecitabine/ cisplatin versus 5-fluorouracil/cisplatin as first-line therapy in patients with advanced gastric cancer: a randomised phase III noninferiority trial. Ann Oncol 2009;20:666-73.

64. Wagner AD, Unverzagt S, Grothe W, Kleber G, Grothey A, Haerting J, Fleig WE. Chemotherapy for advanced gastric cancer. Cochrane Database Syst Rev 2010;(3):CD004064.

65. Van Cutsem E, Moiseyenko VM, Tjulandin S, Majlis A, Constenla M, Boni C, Rodrigues A, Fodor M, Chao Y, Voznyi E, Risse ML, Ajani JA. Phase III study of docetaxel and cisplatin plus fluorouracil compared with cisplatin and fluorouracil as first-line therapy for advanced gastric cancer: a report of the V325 Study Group. J Clin Oncol 2006;24:4991-7.

66. Lorenzen S, Pauligk C, Homann N, Schmalenberg H, Jäger E, Al-Batran SE. Feasibility of perioperative chemotherapy with infusional 5-FU, leucovorin, and oxaliplatin with (FLOT) or without (FLO) docetaxel in elderly patients with locally advanced esophagogastric cancer. Br J Cancer 2013;108:519-26.

67. Kang JH, Lee SI, Lim do H, Park KW, Oh SY, Kwon HC, Hwang IG, Lee SC, Nam E, Shin DB, Lee J, Park JO, Park YS, Lim HY, Kang WK, Park SH. Salvage chemotherapy for pretreated gastric cancer: a randomized phase III trial comparing chemotherapy plus best 
supportive care with best supportive care alone. J Clin Oncol 2012;30:1513-8.

68. Hironaka S, Ueda S, Yasui H, Nishina T, Tsuda M, Tsumura T, Sugimoto N, Shimodaira H, Tokunaga S, Moriwaki T, Esaki T, Nagase M, Fujitani K, Yamaguchi K, Ura T, Hamamoto Y, Morita S, Okamoto I, Boku N, Hyodo I. Randomized, open-label, phase III study comparing irinotecan with paclitaxel in patients with advanced gastric cancer without severe peritoneal metastasis after failure of prior combination chemotherapy using fluoropyrimidine plus platinum: WJOG 4007 trial. J Clin Oncol 2013;31:4438-44.

69. Thuss-Patience PC, Kretzschmar A, Bichev D, Deist T, Hinke A, Breithaupt K, Dogan Y, Gebauer B, Schumacher G, Reichardt P. Survival advantage for irinotecan versus best supportive care as second-line chemotherapy in gastric cancer--a randomised phase III study of the Arbeitsgemeinschaft Internistische Onkologie (AIO). Eur J Cancer 2011;47:2306-14.

70. Ford HE, Marshall A, Bridgewater JA, Janowitz T, Coxon FY, Wadsley J, Mansoor W, Fyfe D, Madhusudan S, Middleton GW, Swinson D, Falk S, Chau I, Cunningham D, Kareclas P, Cook N, Blazeby JM, Dunn JA. Docetaxel versus active symptom control for refractory oesophagogastric adenocarcinoma (COUGAR-02): an open-label, phase 3 randomised controlled trial. Lancet Oncol 2014;15:78-86.

71. Tey J, Back MF, Shakespeare TP, Mukherjee RK, Lu JJ, Lee KM, Wong LC, Leong CN, Zhu M. The role of palliative radiation therapy in symptomatic locally advanced gastric cancer. Int J Radiat Oncol Biol Phys 2007;67:385-8.

72. Tey J, Soon YY, Koh WY, Leong CN, Choo BA, Ho F, Vellayappan B, Lim K, Tham IW. Palliative radiotherapy for gastric cancer: a systematic review and meta-analysis. Oncotarget 2017;8:25797-805.

73. Wilke H, Muro K, Van Cutsem E, Oh SC, Bodoky G, Shimada Y, Hironaka S, Sugimoto N, Lipatov O, Kim TY, Cunningham D, Rougier P, Komatsu Y, Ajani J, Emig M, Carlesi R, Ferry D, Chandrawansa K, Schwartz JD, Ohtsu A; RAINBOW Study Group. Ramucirumab plus paclitaxel versus placebo plus paclitaxel in patients with previously treated advanced gastric or gastro-oesophageal junction adenocarcinoma (RAINBOW): a double-blind, randomised phase 3 trial. Lancet Oncol 2014;15:1224-35.

74. Fuchs CS, Tomasek J, Yong CJ, Dumitru F, Passalacqua R, Goswami C, Safran H, Dos Santos LV, Aprile G, Ferry DR, Melichar B, Tehfe M, Topuzov E, Zalcberg JR, Chau I, Campbell W, Sivanandan C, Pikiel J, Koshiji M, Hsu Y, Liepa AM, Gao L, Schwartz JD, Tabernero J; REGARD Trial Investigators. Ramucirumab monotherapy for previously treated advanced gastric or gastro-oesophageal junction adenocarcinoma (REGARD): an international, randomised, multicentre, placebo-controlled, phase 3 trial. Lancet 2014;383:31-9.

75. Kang YK, Boku N, Satoh T, Ryu MH, Chao Y, Kato K, Chung HC, Chen JS, Muro K, Kang WK, Yeh KH, Yoshikawa T, Oh SC, Bai LY, Tamura T, Lee KW, Hamamoto Y, Kim JG, Chin K, Oh DY, Minashi K, Cho JY, Tsuda M, Chen LT. Nivolumab in patients with advanced gastric or gastro-oesophageal junction cancer refractory to, or intolerant of, at least two previous chemotherapy regimens (ONO-4538-12, ATTRACTION-2): a randomised, double-blind, placebo-controlled, phase 3 trial. Lancet 2017;390:2461-71.

76. Kang YK, Rha SY, Tassone P, Barriuso J, Yu R, Szado T, Garg A, Bang YJ. A phase IIa dose-finding and safety study of first-line pertuzumab in combination with trastuzumab, capecitabine and cisplatin in patients with HER2-positive advanced gastric cancer. Br J Cancer 2014;111:660-6.

77. Ohtsu A, Shah MA, Van Cutsem E, Rha SY, Sawaki A, Park SR, Lim HY, Yamada Y, Wu J, Langer B, Starnawski M, Kang YK. Bevacizumab in combination with chemotherapy as first- line therapy in advanced gastric cancer: a randomized, double- blind, placebocontrolled phase III study. J Clin Oncol 2011;29:3968-76.

78. Lordick F, Kang YK, Chung HC, Salman P, Oh SC, Bodoky G, Kurteva G, Volovat C, Moiseyenko VM, Gorbunova V, Park JO, Sawaki A, Celik I, Götte H, Melezínková H, Moehler M. Capecitabine and cisplatin with or without cetuximab for patients with previously untreated advanced gastric cancer (EXPAND): a randomised, open-label phase 3 trial. Lancet Oncol 2013;14:490-9.

79. Waddell T, Chau I, Cunningham D, Gonzalez D, Okines AF, Okines C, Wotherspoon A, Saffery C, Middleton G, Wadsley J, Ferry D, Mansoor W, Crosby T, Coxon F, Smith D, Waters J, Iveson T, Falk S, Slater S, Peckitt C, Barbachano Y. Epirubicin, oxaliplatin, and capecitabine with or without panitumumab for patients with previously untreated advanced oesophagogastric cancer (REAL3): a randomised, open-label phase 3 trial. Lancet Oncol 2013;14:481-9.

80. Thuss-Patience PC, Shah MA, Ohtsu A, Van Cutsem E, Ajani JA, Castro H, Mansoor W, Chung HC, Bodoky G, Shitara K, Phillips GDL, van der Horst T, Harle-Yge ML, Althaus BL, Kang YK. Trastuzumab emtansine versus taxane use for previously treated HER2-positive locally advanced or metastatic gastric or gastro-oesophageal junction adenocarcinoma (GATSBY): an international randomised, open-label, adaptive, phase 2/3 study. Lancet Oncol 2017;18:640-53.

81. The Cancer Genome Atlas Research Network. Comprehensive molecular characterization of gastric adenocarcinoma. Nature 2014;513:2029.

82. Kakiuchi M, Nishizawa T, Ueda H, Gotoh K, Tanaka A, Hayashi A, Yamamoto S, Tatsuno K, Katoh H, Watanabe Y, Ichimura T, Ushiku T, Funahashi S, Tateishi K, Wada I, Shimizu N, Nomura S, Koike K, Seto Y, Fukayama M, Aburatani H, Ishikawa S. Recurrent gain-offunction mutations of RHOA in diffuse-type gastric carcinoma. Nat Genet 2014;46:583-7.

83. Ushiku T, Ishikawa S, Kakiuchi M, Tanaka A, Katoh H, Aburatani H, Lauwers GY, Fukayama M. RHOA mutation in diffuse-type gastric cancer: a comparative clinicopathology analysis of 87 cases. Gastric Cancer 2016;19:403-11.

84. Hansford S, Kaurah P, Li-Chang H, Woo M, Senz J, Pinheiro H, Schrader KA, Schaeffer DF, Shumansky K, Zogopoulos G, Santos TA, Claro I, Carvalho J, Nielsen C, Padilla S, Lum A, Talhouk A, Baker-Lange K, Richardson S, Lewis I, Lindor NM, Pennell E, MacMillan A, Fernandez B, Keller G, Lynch H, Shah SP, Guilford P, Gallinger S, Corso G, Roviello F, Caldas C, Oliveira C, Pharoah PD, Huntsman DG. Hereditary diffuse gastric cancer syndrome: CDH1 mutations and beyond. JAMA Oncol 2015;1:23-32. 